\title{
Lembaga Keuangan Mikro dan Kedudukannya Dalam Perekonomian Islam
}

\author{
Try Subakti, Nurhidayah Marsono \\ Institut Agama Islam Negeri Madura \\ Email : try.subakti@gmail.com, nurhidayah.marsono@gmail.com
}

\begin{abstract}
Abstrak
Artikel ini membahas tentang BMT, dimana Baitul Māl wat Tamwil (BMT) adalah balai usaha mandiri terpadu yang isinya berintikan bayt al-mal wa altamwil dengan kegiatan mengembangkan usaha-usaha produktif dan investasi dalam meningkatkan kualitas kegiatan ekonomi pengusaha kecil bawah dan kecil dengan antara lain mendorong kegiatan menabung dan menunjang pembiayaan kegiatan ekonominya. Selain itu, Baitul Māl wat Tamwil juga bisa menerima titipan zakat, infak, sedekah, serta menyalurkannya sesuai dengan peraturan dan amanatnya. Baitul Mãl wat Tamwil yang sebenarnya dalam konsepsi Islam merupakan alternatif kelembagaan keuangan syari'ah yang memiliki dimensi sosial dan produktif dalam skala nasional bahkan global, di mana perekonomian umat terpusat pada fungsi kelembagaan ini yang mengarah pada hidupnya fungsi-fungsi kelembagaan ekonomi lainnya. BMT melakukan fungsi lembaga keuangan, yaitu melakukan kegiatan penghimpunan dana masyarakat, penyaluran dana kepada masyarakat, dan memberikan jasa-jasa lainnya.
\end{abstract}

Kata Kunci: BMT, Pembiayaan, Ekonomi, Bank Syariah

\section{Pendahuluan}

Ekonomi Islam merupakan ilmu pengetahuan sosial yang mempelajari masalahmasalah ekonomi rakyat yang diilhami oleh nilai-nilai Islam. Bersamaan dengan semakin semangatnya masyarakat untuk mempelajari agama, mulai banyak bermunculan beberapa lembaga ekonomi yang menerapkan prinsip-prinsip Islam seperti perbankan, asuransi dan Baitul Māl wat Tamwil yang biasa kita kenal dengan BMT. Umat Islam sebagai komponen terbesar bangsa Indonesia mau tidak mau harus berkiprah dalam kancah pemberdayaan dan peningkatan ekonomi kerakyatan, terutama kalangan ekonomi lemah. Baitul Māl wat Tamwil ini mulai populer diperbincangkan 
oleh insan perekonomian terutama dalam perekonomian Islam. BMT merupakan salah satu lembaga keuangan Islam yang mana sistemnya hampir mirip dengan sistem pada perbankan. Penghimpunan dana yang diperoleh BMT yakni melalui simpanan.dimana BMT itu sendiri menjadi wadah dalam mengelola dana sosial seperti zakat, wakaf, infak dan sedekah. Dengan kehadiran BMT diharapkan mampu menjadi sarana dalam menyalurkan dana untuk bisnis kecil dengan mudah dan bersih, lembaga keuangan alternatif yang mudah diakses oleh masyarakat bawah dan bebas riba, lembaga untuk memberdayakan ekonomi ummat, mengentaskan kemiskinan dan meningkatkan produktivitas. Peran umum BMT adalah melakukan pembinaan dan pendanaan yang berdasarkan sistem syariah. Peran ini menegaskan arti penting prinsip-prinsip syariah dalam kehidupan ekonomi masyarakat. Sebagai lembaga keuangan syariah yang bersentuhan langsung dengan kehidupan masyarakat kecil yang serba cukup maka BMT mempunyai tugas penting dalam penemban misi keislaman dalam segala aspek kehidupan masyarakat. ${ }^{1}$

\section{Pembahasan}

BMT adalah kependekan kata Balai Usaha Mandiri Terpadu atau Baitul Māl wat Tamwil, yaitu lembaga keuangan mikro (LKM) yang beroperasi berdasarkan prinsip-prinsip syariah. BMT sesuai namanya terdiri dari dua fungsi utama, yaitu²:

1. Baitul tamwil (rumah pengembangan harta), melakukan kegiatan pengembangan usaha-usaha produktif dan investasi dalam meningkatkan kualitas ekonomi pengusaha mikro dan kecil dengan antara lain mendorong kegiatan menabung dan menunjang pembiayaan kegiatan ekonomi.

2. Baitul mal (rumah harta), menerima titipan dana zakat, infak dan sedekah serta mengoptimalkan distribusinya sesuai dengan peraturan dan amanahnya.

Baitul Māl wat Tamwil adalah lembaga keuangan mikro yang dioperasikan dengan prinsip bagi hasil, menumbuhkembangkan bisnis usaha mikro dan kecil dalam rangka mengangkat martabat dan serta membela kepentingan kaum fakir miskin. Secara konseptual, BMT memiliki dua fungsi Baitul Tamwil (Bait = Rumah, At Tamwil =

\footnotetext{
${ }^{1}$ Heri Sudarsono, Bank dan Lembaga Keuangan Syariah, (Yogyakarta: Ekonisia, 2003), h.84

${ }^{2}$ Andri Soemitra, Bank dan Lembaga Keuangan Syariah, cet. ke-3, (Jakarta: kencana, 2012), h. 
Pengembangan Harta). Jadi BMT adalah balai usaha mandiri terpadu yang isinya berintikan bayt al-mal wa al-tamwil dengan kegiatan mengembangkan usaha-usaha produktif dan investasi dalam meningkatkan kualitas kegiatan ekonomi pengusaha bawah dan kecil dengan antara lain mendorong kegiatan menabung dan menunjang pembiayaan kegiatan. ${ }^{3}$

Sebagai lembaga usaha yang mandiri, BMT memiliki ciri-ciri sebagai berikut ${ }^{4}$ :

1. Berorientasi bisnis, yaitu memiliki tujuan untuk mencari laba bersama dan meningkatkan pemanfaatan segala potensi ekonomi yang sebanyak-banyaknya bagi para anggota dan lingkungannya.

2. Bukan merupakan lembaga sosial, tetapi dapat dimanfaatkan untuk mengelola dana sosial umat, seperti zakat, infak, sedekah, hibah, dan wakaf.

3. Lembaga ekonomi umat yang dibangun dari bawah secara swadaya yang melibatkan peran serta masyarakat sekitarnya.

4. Lembaga ekonomi milik bersama antara kalangan masyarakat bawah dan kecil serta bukan milik perorangan atau kelompok tertentu di luar masyarakat sekitar BMT.

\section{Kegiatan Operasional}

Berdasarkan fungsi dan jenis dana yang dikelola oleh BMT, maka terdapat dua tugas penting BMT, yakni terkait dengan pengumpulan dan penggunaan dana. ${ }^{5}$

\section{Pengumpulan Dana BMT}

Pengumpulan dana BMT dilakukan melalui bentuk simpanan tabungan dan deposito. Adapun akad yang mendasari berlakunya simpanan terikat atas jangka waktu dan syarat-syarat tertentu dalam penyertaan dan penarikannya, yakni:

a. Simpanan wadiah, adalah titipan dana yang tiap waktu dapat ditarik pemilik atau anggota dengan mengeluarkan semacam surat berharga pemindahbukuan atau transfer dan perintah membayar lainnya. Simpanan yang berakad wadiah ada dua macam, yakni wadiah amanah, yaitu titipan dana zakat, infak dan shadaqah

\footnotetext{
3 Abdul aziz dan Mariyah ulfah, Kapita Selekta Ekonomi Islam Kontemporer, (Bandung: Alfabeta, 2010), h. 115

${ }^{4}$ Ahmad Hasan Ridwan, Manajemen Baitul Mal wa tamwil, cet. ke-1, (Bandung: Pustaka Setia, 2013), h. 24

5 Buchari Alma dan Donni Juni Priansa, Manajemen Bisnis Syariah, cet. ke-1, (Bandung: Alfabeta, 2009), h. 19-20
} 
dan wadiah yadhomanah, yaitu titipan yang akan mendapat bonus dari pihak bank syariah jika bank syariah mengalami keuntungan.

b. Simpanan mudharabah, adalah simpanan pemilik dana yang penyetoran dan penarikannya dapat dilakukan sesuai dengan perjanjian yang telah disepakati sebelumnya. Pengkongsian antara dua pihak, dimana pihak pertama menyediakan dana, dan pihak kedua bertanggung jawab atas pengelolaan usaha. ${ }^{6}$ Simpanan mudharabah tidak memberikan bunga tetapi diberikan bagi hasil.

Sumber dana BMT antara lain berasal dari dana masyarakat, simpanan biasa, simpanan berjangka atau deposito, serta melalui kerja sama antar institusi. Hal-hal yang perlu diperhatikan dalam penggalangan dana antara lain momentum, prospek usaha, rasa aman, dan profesionalisme.

1) Penyaluran Dana BMT

Dana yang dikumpulkan dari anggota harus disalurkan dalam bentuk pinjaman kepada anggotanya. Pinjaman dana kepada anggota disebut juga pembiayaaan, yaitu suatu fasilitas yang diberikan BMT kepada anggota yang membutuhkan untuk menggunakan dana yang telah dikumpulkan BMT dari anggota yang surplus dana.

Terdapat berbagai jenis pembiayaan yang dikembangkan oleh BMT, yang semuanya itu mengacu pada dua jenis akad, yakni akad tijarah dan akad syirkah. ${ }^{7}$

1. Akad tijarah (jual beli), yakni suatu perjanjian pembayaan yang disepakati antara BMT dengan anggota dimana BMT enyediakan dananya untuk sebuah investasi dan atau pembelian barang modal dan usaha anggotanya yang kemudian proses pembayarannya dilakukan secara mencicil atau angsuran atau pengembalian dibayarkan pada saat jatuh tempo pengembaliannya.

2. Akad syirkah (penyertaan dan bagi hasil)

- Musyarakah: penyertaan BMT sebagai pemilik modal dalam suatu usaha yang mana antara resiko dan keuntungan ditanggung bersama secara seimbang dengan porsi penyertaan.

- Mudharabah: suatu perjanjian pembiayaan antara BMT dengan anggota dimana BMT menyediakan dana untuk penyediaan modal kerja sedangkan peminjam berupaya mengelola dna tersebut untuk pengembangan usahanya.

\footnotetext{
${ }^{6}$ Ibid., h. 10

${ }^{7}$ Ibid., h. 20
} 
Dalam operasionalnya, BMT dapat menjalankan berbagai jenis kegiatan usaha, baik yang berhubungan dengan keuangan maupun non-keuangan. Adapun jenis-jenis usaha BMT yang berhubungan dengan keuangan dapat berupa ${ }^{8}$ :

1) Setelah mendapatkan modal awal berupa simpanan pokok khusus, simpanan pokok, dan simpanan wajib sebagai modal dasar BMT, selanjutnya BMT memobilisasi dana dengan mengembangkannya dalam aneka simpanan sukarela (semacam tabungan umum) dengan berasaskan akad mudarabah dari anggota berbentuk:
a) Simpanan biasa
b) Simpanan pendidikan
c) Simpanan haji
d) Simpanan umrah
e) Simpanan qurban
f) Simpanan Idul Fitri
g) Simpanan walimah
h) Simpanan akikah
i) Simpanan perumahan (pembangunan dan perbaikan)
j) Simpanan kunjungan wisata, dan
k) Simpanan mudarabah berjangka (semacam deposito 1, 3, 6, 12 bulan). Dengan akad wadi'ah (titipan tidak berbagi hasil), di antaranya:
a) Simpanan yad al-amanah: titipan dana zakat, infak, dan sedekah untuk disampaikan kepada yang berhak.
b) Simpanan yad ad-dhamanah: giro yang sewaktu-waktu dapat diambil oleh penyimpan.

2) Kegiatan pembiayaan/kredit usaha kecil bawah (mikro) dan kecil, antara lain dapat berbentuk: ${ }^{9}$

a. Pembiayaan mudharabah, yaitu pembiayaan total dengan menggunakan mekanisme bagi hasil.

b. Pembiayaan musyarakah, yaitu pembiayaan bersama dengan menggunakan mekanisme bagi hasil.

${ }^{8}$ Andri Soemitra, Bank dan Lembaga Keuangan Syariah, cet. ke-3, (Jakarta: kencana, 2012), h. 463-464

${ }^{9}$ Ibid., h. 464. 
c. Pembiayaan murabahah, yaitu pemilikan suatu barang tertentu yang dibayar pada saat jatuh tempo.

d. Pembiayaan bay' bi saman ajil, yaitu pemilikan suatu barang tertentu dengan mekanisme pembayaran cicilan.

e. Pembiayaan qard al-hasan, yaitu pinjaman tanpa adanya tambahan pengembalian kecuali sebatas biaya administrasi.

Selain kegiatan yang berhubungan dengan keuangan di atas, BMT dapat juga mengembangkan usaha di bidang sektor riil, seperti kios telepon, kios benda pos, memperkenalkan teknologi maju untuk peningkatan produktivitas hasil para anggota, menodorng tumbuhnya industri rumah tangga atau pengolahan hasil, mempersiapkan jaringan perdagangan atau pemasaran masukan dan hasil produksi, serta usaha lain yang layak, menguntungkan dan tidak mengganggu program jangka pendek, dengan syarat dikelola dengan sistem manajemen yang terpisah dan profesional.

2. Fungsi BMT dalam perekonomian umat usaha mikro

BMT bersifat terbuka, independen, tidak partisan, berorientasi pada pengembangan tabungan dan pembiayaan untuk mendukung bisnis ekonomi yang produktif bagi anggota dan kesejahteraan sosial masyarakat sekitar, terutama usaha mikro dan fakir miskin.

Dalam rangka mencapai tujuannya, BMT berfungsi sebagai berikut ${ }^{10}$ :

a. Mengidentifikasi, memobilisasi, mengorganisasi, mendorong dan mengembangkan potensi serta kemampuan potensi ekonomi anggota, kelompok anggota muamalat (pokusma) dan daerah kerjanya.

b. Meningkatkan kualitas SDM anggota dan pokusma menjadi lebih profesional dan islami sehingga semakin utuh dan tangguh dalam menghadapi persaingan global.

c. Menggalang dan memobilisasi potensi masyarakat dalam rangka meningkatkan kesejahteraan anggota.

d. Menjadi perantara keuangan (financial intermediary) antara agniya sebagai shohibul māl dengan du'afa sebagai mudhorib, terutama untuk dana-dana sosial seperti zakat, infaq, sedekah, wakaf, hibah, dll.

${ }^{10}$ Muhammad Ridwan, Manajemen Baitul Maal Wa Tamwil (BMT), cet. ke-2, (Yogyakarta: UII Press, 2005), h. 131 
e. Menjadi perantara keuangan, antara pemilik dana (shohibul māl), baik sebagai pemodal maupun penyimpan dengan pengguna dana (modhorib) untuk pengembangan usaha produktif.

Fungsi BMT untuk masyarakat adalah ${ }^{11}$ :

a. Meningkatkan kualitas SDM anggota, pengurus, dan pengelola menjadi lebih profesional, salām (selamat, damai, dan sejahtera), dan amanah sehingga semakin utuh dan tangguh dalam berjuang dan berusaha (beribadah) menghadapi tantangan global.

b. Mengorganisasi dan memobilisasi dana sehingga dana yang dimiliki oleh masyarakat dapat termanfaatkan secara optimal di dalam dan di luar orgnisasi untuk kepentingan rakyat banyak.

c. Mengembangkan kesempatan kerja.

d. Mengukuhkan dan meningkatkan kualitas usaha dan pasar produk-produk anggota.

e. Memperkuat dan meningkatkan kualitas lembaga-lembaga ekonomi dan sosial masyarakat banyak.

Perkembangan ekonomi syariah di Indonesia mengalami perkembangan yang cukup pesat. Hal ini ditandai dengan banyak berdirinya lembaga keuangan yang secara operasional menggunakan prinsip bagi hasil atau dikenal dengan prinsip syariah.

Beberapa kalangan membuat penilaian tersebut dari segi keberadaan dan peranan lembaga keuangan syariah, sedangkan mengukur segi sosialisasi sistem ekonomi syariah kepada masyarakat relatif masih terbatas. Padahal sosialisasi ekonomi syariah kepada masyarakat merupakan aspek penunjang dalam strategi pengembangan ekonomi syariah di Indonesia.

Wawasan dan pengetahuan tentang ekonomi syariah umumnya hanya di kalangan akademisi dan praktisi lembaga keuangan syariah, sedangkan masyarakat bawah belum tentu mengenal dan memahaminya secara jelas. Padahal ekonomi syariah merupakan sistem ekonomi yang lebih memberikan daya tawar positif, tidak hanya dari aspek hukum, tetapi uga bisa menjadi sistem ekonomi alternatif yang dapat mendukung proses percepatan pembangunan ekonomi di Indonesia.

11 Nur Rianto Al-Arif, Lembaga Keuangan Syariah (suatu kajian teoretis praktis), cet. ke-1, (Bandung: Pustaka Setia, 2012), h. 325 
BMT bukan lembaga pemerintah atau lembaga independen yang dapat bekerja sendiri. BMT tidak akan berfungsi efektif karena lembaga ini memerlukan dukungan dari banyak pihak, baik lembaga pemerintah maupun swasta. Bahkan, kunci dari dukungan terhadap BMT adalah komponen masyarakat. Dukungan masyarakat terhadap optimalisasi peran BMT sangat penting sebab lembaga BMT didirikan dari, oleh, dan untuk masyarakat. Segala ide dasar dan tujuan dari didirikannya BMT adalah untuk kepentingan masyarakat sendiri dan dilakukan secara swadaya dan berkesinambungan.

Jika dilihat dalam kerangka sistem ekonomi Islam, tujuan BMT dapat berperan melakukan hal-hal berikut ${ }^{12}$ :

a. Membantu meningkatkan dan mengembangkan potensi umat dalam program pengentasan kemiskinan.

b. Memberikan sumbangan aktif terhadap upaya pemberdayaan dn peningkatan kesejahteraan umat.

c. Menciptakan sumber pemiayaan dan penyediaan modal bagi anggota dengan prinsip syariah.

d. Mengembangkan sikap hemat dan mendorong kegiatan gemar menabung.

e. Menumbuh kembangkan usaha-usaha yang produktif dan sekaligus memberikan bimbingan dan konsultasi bagi anggota di bidang usahanya.

f. Meningkatkan wawasan dan kesadaran umat tentang sistem dan pola perekonomian Islam.

g. Membantu para pengusaha lemah untuk mendapatkan modal pinjaman.

h. Menjadi lembaga keuangan elternatif yang dapat menopang percepatan pertumbuhan ekonomi nasional.

Sebagai lembaga pengelola dana masyarakat dalam skala kecil dan menengah, BMT menawarkan pelayanan jasa dalam bentuk kredit dan pembiayaan kepada masyarakat. Beberapa manfaat yang dapat diperoleh dari pelayanan BMT, antara lain ${ }^{13}$ :

a. Meraih keuntungan bagi hasil dan investasi dengan cara syariah

\footnotetext{
12 Ahmad Hasan Ridwan, Manajemen Baitul Mal wa tamwil, cet. ke-1, (Bandung: Pustaka Setia, 2013), h. 37-38

${ }^{13}$ Ibid., h. 44-45.
} 
b. Pengelolaan dana berdasarkan nilai-nilai kejujuran dan keadilan akan menjadikan setiap simpanan dan pinjaman di BMT aman, baik secara syari'i maupun ekonomi.

c. Komitmen pada ekonomi kerakyatan, BMT membuat setiap transaksi keuangan, memperoleh kredit berikut pengelolaannya bermanfaat bagi pengembangan ekonomi umat Islam.

d. BMT dan masyarakat dapat berperan membangun citra perekonomian yang dikelola umat Islam.

e. Menggairahkan usaha-usaha kecil produktif dan membebaskan mereka dari jeratan rentenir

f. Partisipasi positif bagi kemajuan lembaga-lembaga keuangan dan perbankan Islam termasuk di dalamnya BMT

Selain itu, BMT juga memiliki beberapa keunggulan, yaitu ${ }^{14}$ :

1) Adanya jaminan pelayanan jasa keuangan berdasarkan prinsip syariah dan bebas dari praktik riba.

2) Masyarakat dapat memperoleh pelayanan langsung, cepat, dan mudah dalam menyimpan atau meminjam dana berdasarkan prinsip bagi hasil.

3) BMT dan nasabah dapat berbagi resiko karena masing-masing memiliki hak dan kewajiban yang sama sesuai dengan proporsinya.

4) Terhindarnya praktik-praktik manipulasi dan monopoli keuangan karena praktisi BMT memegang teguh prinsip amanah, kejujuran, dan keadilan.

5) Adanya pemerataan dan keseimbangan dalam perolehan keuntungan bersama.

Manfaat dan keunggulan yang dimiliki BMT tersebut merupakan penjabaran dari sistem ekonomi Islam. Sebagai instrumen lembaga keuangan syariah, BMT juga banyak memberikan perhatian pada pengembangan usaha kecil dan menengah di Indonesia, khususnya dalam pemberdayaan ekonomi masyarakat lemah.

\section{Prinsip Dan Produk Inti Dari Baitul Māl wat Tamwil}

Baitul Māl wat Tamwil sebenarnya merupakan dua kelembagaan yang menjadi satu, yaitu lembaga Baitul Māl dan lembaga Baitut Tamwil yang masing-masing

\footnotetext{
${ }^{14}$ Ibid., h. 45.
} 
keduanya memiliki prinsip dan produk yang berbeda meskipun memiliki hubungan yang erat antara keduanya dalam menciptakan suatu kondisi perekonomian yang merata dan dinamis.

Secara ringkas P3UK (1994) menerangkan prinsip dan produk inti dari Baitul Māl wat Tamwil adalah sebagai berikut: ${ }^{15}$

a. Prinsip dan Produk inti Baitul Mãl

Memiliki prinsip sebagai sebagai penghimpun dan penyalur dana zakat, infaq, dan shadaqah-nya. Dapat diungkapkan bahwa produk inti dari Baitul Māl terdiri atas:

1) Produk Penghimpun Dana

Baitul Māl menerima dan mencari dana berupa zakat, infaq, dan shadaqah, dan juga menerima dana berupa sumbangan, hibah, atau wakaf serta dana-dana yang sifatnya sosial.

2) Produk Penyaluran Dana

Penyaluran dana harus bersifat spesifik, terutama dana yang bersumber dari zakat, karena sudah ditetapkan dalam nash, yaitu kepada 8 asnaf. Sedangkan dana di luar zakat dapat digunakan untuk pengembangan usaha orang-orang miskin, pembangunan lembaga pendidikan, masjid maupun biayabiaya operasional kegiatan sosial lainnya. ${ }^{16}$

b. Prinsip dan Produk inti Baitut Tamwil

Dalam Baitut Tamwil tidak jauh berbeda dengan prinsip-prinsip yang digunakan Bank Islam. Ada tiga prinsip yang dilaksanakan oleh BMT dalam fungsinya sebagai Baitut Tamwil, yaitu: ${ }^{17}$

1) Prinsip bagi hasil

Prinsip ini merupakan suatu sistem yang meliputi tatacara pembagian hasil usaha antara pemodal dengan pengelola dana. Pembagian bagi hasil ini dilakukan antara BMT dengan pengelola dana dan antara BMT dan penyedia dana. Bentuk produk yang berdasarkan prinsip ini adalah Mudharabah dan Musyarakah.

2) Prinsip jual beli dengan keuntungan (Mark-up)

\footnotetext{
${ }^{15}$ Jamal Lulail Yunus, Manajemen Bank Syari'ah, (Malang: UIN-Malang Press, 2009), h. 33

${ }^{16}$ Ibid., h. 34

${ }^{17}$ Ibid., h. 35
} 
Prinsip ini merupakan suatu tata cara jual beli yang dalam pelaksanaanya BMT mengangkat nasabah sebagai agen (yang diberi kuasa) melakukan pembelian barang atas nama BMT, kemudian BMT bertindak sebagai penjual, menjual barang tersebut kepada nasabah dengan harga sejumlah harga beli ditambah keuntungan bagi BMT atau sering disebut margin Mark-up. Keuntungan yang diperoleh BMT akan dibagi juga kepada penyedia atau penyimpan dana. Bentuk produk prinsip ini adalah Murabahah dan Bai' Bitsaman Ajil.

3) Prinsip non profit

Prinsip ini disebut juga dengan pembiayaan kebijakan, prinsip ini lebih bersifat social dan tidak profit oriented. Sumber dana untuk pembiayaan ini tidak membutuhkan biaya (non cost of money) tidak seperti bentuk-bentuk pembiayaan tersebut diatas. Bentuk produk prinsip ini adalah pembiayaan Qordul Hasan. ${ }^{18}$

\section{Penutup}

BMT adalah balai usaha mandiri terpadu yang isinya berintikan bayt al-mal wa al-tamwil dengan kegiatan mengembangkan usaha-usaha produktif dan investasi dalam meningkatkan kualitas kegiatan ekonomi pengusaha bawah dan kecil dengan antara lain mendorong kegiatan menabung dan menunjang pembiayaan kegiatan. Sebagai lembaga usaha yang mandiri, BMT memiliki ciri-ciri:

1. Berorientasi bisnis, yaitu memiliki tujuan untuk mencari laba bersama dan meningkatkan pemanfaatan segala potensi ekonomi yang sebanyak-banyaknya bagi para anggota dan lingkungannya.

2. Bukan merupakan lembaga sosial, tetapi dapat dimanfaatkan untuk mengelola dana sosial umat, seperti zakat, infak, sedekah, hibah, dan wakaf.

3. Lembaga ekonomi umat yang dibangun dari bawah secara swadaya yang melibatkan peran serta masyarakat sekitarnya.

4. Lembaga ekonomi milik bersama antara kalangan masyarakat bawah dan kecil serta bukan milik perorangan atau kelompok tertentu di luar masyarakat sekitar BMT.

\footnotetext{
${ }^{18}$ Ibid., h. 36-38
} 
BMT dapat dipandang memiliki dua fungsi utama, yaitu sebagai media penyalur pendayagunaan harta ibadah seperti zakat, infak, sedekah dan wakaf, serta dapat pula berfungsi sebagai institusi yang bergerak di bidang investasi yang bersifat produktif sebagaimana layaknya bank. Pada fungsi kedua, dapat dipahami bahwa selain berfungsi sebagai lembaga keuangan, BMT juga berfungsi sebagai lembaga ekonomi. Sebagai lembaga keuangan, BMT bertugas menghimpun dana dari masyarakat (anggota BMT) yang memercayakan dananya disimpan di BMT dan menyalurkan dana kepada masyarakat (anggota BMT) yang diberikan pinjaman oleh BMT. 


\section{Daftar Rujukan}

Al-Arif, Nur Rianto, Lembaga Keuangan Syariah (suatu kajian teoretis praktis), cet. ke-1, Bandung: Pustaka Setia, 2012.

Alma, Buchari dan Donni Juni Priansa, Manajemen Bisnis Syariah, cet. ke-1, Bandung: Alfabeta, 2009.

Aziz, Abdul dan Mariyah ulfah, Kapita Selekta Ekonomi Islam Kontemporer, Bandung: Alfabeta, 2010.

Ridwan, Ahmad Hasan, Manajemen Baitul Mal wa tamwil, cet. ke-1, Bandung: Pustaka Setia, 2013.

Ridwan, Muhammad, Manajemen Baitul Maal Wa Tamwil (BMT), cet. ke-2, Yogyakarta: UII Press, 2005.

Soemitra, Andri, Bank dan Lembaga Keuangan Syariah, cet. ke-3, Jakarta: kencana, 2012.

Sudarsono, Heri, Bank dan Lembaga Keuangan Syariah, Yogyakarta: Ekonisia, 2003.

Yunus, Jamal Lulail, Manajemen Bank Syari'ah, Malang: UIN-Malang Press, 2009. 